\title{
복부외상의 응급처치
}

\section{Emergency Care of Abdominal Trauma}

\author{
임 경 수 | 울산의대 응급의학교실 | Kyoung-Soo Lim, MD \\ Department of Emergency Medicine, Ulsan University of College of Medicine \\ E-mail : kslim@amc.seoul.kr
}

J Korean Med Assoc 2007; 50(8): 7II - 715

\section{Abstract}



\section{서 론}

ए? 발성 외상환자가 내원하는 경우에는 전문외상처치술 (advanced trauma life support, ATLS)의 방법에 의 거하여 소생술을 시행하면서 치료의 우선 순위에 입각하여 각종 응급처치를 시행하게 된다. 둔상(blunt trauma) 후에 혈압이 저하된 다발성 외상환자의 경우에는 우선 복강이나
골반내 출혈의 가능성을 고려해야 한다. 복부에 둔상이 가 해지는 경우에 복강내 장기의 손상빈도 별로 보면 비장손상 이 $40 \sim 55 \%$ 로 가장 많고, 간손상( $35 \sim 45 \%)$, 소장손상 $(5$ $10 \%)$ 의 순이며, 후복막혈종은 $15 \%$ 정도에서 발생한다고 보고되고 있다(1). 또한 유두선(nipple line)에서 회음부까 지의 몸통 자상(penetrating injury)를 받은 경우에도 복강 내 장기손상의 가능성을 반드시 고려해야 한다(1). 공기를 
뱉는 호기시에는 횡격막이 제5늑간(유두선)까지 도달하는 데, 이 때 자상을 입으면 복강내 장기가 손상될 수 있기 때문 이다.

\section{복부손상의 신속한 진단}

초기에는 응급의료진이 복부손상의 유무를 신속히 판단 하는 것이 매우 중요한데, 전문외상처치술의 1 차 평가 중 혈 압이 저하된 경우에는 소생실에서 직접 외상초음파(focused assessment sonography in trauma, FAST)를 시행하여 심낭압전이나 혈복증의 유무를 진단한다(2). 외상초음파로 혈복증을 진단하는 방법은 $3.5 \mathrm{MHz}$ 탐촉자를 이용하여 양 측 횡격막 하부, 모리슨와(Morison's pouch), 더글라스와 (Douglas culde sac) 등에서 혈액 혹은 저류액의 유무를 확 인하는 것이다. 초음파검사를 시행하여도 초기에는 소량의 출혈을 진단할 수 없으므로, 다발성 외상 환자의 경우에는 외상초음파를 시행한 후에도 30 분 간격으로 반복적으로 시 행하는 것이 바람직하다.

환자가 복통을 호소하거나 신체검진에서 복부자각징후 (peritoneal irritation sign)가 발견되면 복막염이나 혈복증 의 유무를 검사해야 한다. 다만, 소량의 출혈에 의한 혈복증 이나 소장이 천공된 초기에는 복통이나 복부자각징후가 매 우 경미할 수 있으므로 주의해야 한다. 소장의 내용물은 위 나 대장의 내용물에 비하여 비교적 중성(neutral $\mathrm{pH}$ )이고 멸균상태(sterile fluid)이며 소량이기 때문에 소장이 천공 된 초기에는 복막염의 징후가 거의 나타나지 않는다. 소량 의 혈복증인 경우에도 초기에는 생체징후나 복부자각증상 이 거의 없기 때문에 복부손상이 의심되거나 생체징후의 변 화가 나타나는 경우에는 반복적으로 복부영상검사를 시행 해야 한다.

응급실에서 이용하는 복부영상방법 중에서 가장 흔한 방 법은 초음파검사이다. 이미 언급한 경우와 같이 외상초음파 (FAST)를 이용하여 혈복증의 유무를 신속히 판정하는데, 외 상초음파검사는 환자의 이동 없이 소생실 침상 옆에서 즉시 시행할 수 있으며 수 시간의 교육으로 술기를 시행할 수 있 고 반복적으로 검사할 수 있는 비침습적 검사방법이라는 장
Table 1. Abdominal images to evaluate abdominal injury

FAST (focused assessment sonography in trauma) Simple X-ray of chest, abdomen and pelvis Urethrography and cystography Contrast-enhanced CT IVP (intra-venous pyelography) if CT is not available

Table 2. Positive findings of diagnostic peritoneal lavage in blunt trauma

Aspiration of gross blood(more than $10 \mathrm{ml}$ ) or $\mathrm{Gl}$ contents $\mathrm{RBC}>100,000 / \mathrm{mm}^{3}$

$\mathrm{WBC} \geq 500 / \mathrm{mm}^{3}$

Gram stain with bacteria (+)

점이 있다(2). 단순 방사선검사로서는 흥부 혹은 복부 단순 촬영이 도움이 되기도 하는데, 횡격막 하부나 후복막강 내 의 유리가스(free air)가 관찰되면 복막염을 의심하고, 복부 지방선(peritoenal fat line) 혹은 psoas shadow가 소실되 면 복강내 장기손상을 의심할 수 있다. 그러나 단순 방사선 검사는 신뢰도가 낮기 때문에 다른 정밀검사를 추가로 시행 해야 한다. 복부손상의 유무를 판정하기 위하여 응급실에서 시행하는 영상검사의 종류는 다음과 같다.

복부전산화단층활영을 시행하는 경우에는 횡격막 상부 $1 \sim 2 \mathrm{~cm}$ 정도부터 촬영을 시작하여 골반부까지 계속하는 것 이 바람직한데, 횡격막 상부의 영상에서는 혈흉이나 기흥의 유무를 확인하기 위해서다. 또한 복부전산화촬영이 종료된 직후에 복부 단순방사선검사(simple X-ray of abdomen) 를 시행하면 전산촬영 때 투여한 조영제가 비뇨기계로 유출 되는 경로가 나타나므로 간접적인 IVP의 효과를 얻을 수 있 으므로 비뇨기 계통의 손상 유무를 판정할 수 있다(2).

진단적 복강세척술(diagnostic peritoneal lavage, DPL) 은 과거에 많이 사용되었으나 외상초음파검사가 도입된 이 후 국내에서는 약 10 여년 전부터는 거의 이용하지 않는 침 습적 진단법이다. 배꼽의 하부 $2 \mathrm{~cm}$ 복부를 절개하여 복강 내로 수액 1리터(소아는 $10 \mathrm{ml} / \mathrm{kg}$ )를 투여한 후에 다시 복강 내의 내용물을 역류시켜서 내용물을 분석하는 방법이다(1). 진단적 복강세척술은 감수성이 $98 \%$ 로 매우 높으나 위양성 (false positive)의 확률이 높다는 단점이 있으며, 최근에는 
Table 3. Diagnostic peritoneal lavage versus focused assessment sonography in trauma versus CT in blunt abdominal trauma

\begin{tabular}{llll}
\hline & FAST* & DPL $^{\dagger}$ & CT scan \\
\hline Indication & Document fluid if hypotensive & Document bleeding if hypotensive & Document organ injury if hypotensive \\
& Early diagnosis & Early diagnosis & Most specific for injury \\
& All patients & All patients & Sensitive: $92 \sim 98 \%$ accurate \\
& Noninvasive & Performed rapidly & \\
Advantage & Performed rapidly & $98 \%$ sensitive & \\
& Repeatable & Detects bowel injury & \\
& High accuracy: 86 97\% & Transport: No & \\
& Transport: No & & High cost and time \\
& Operator-dependent & Invasive & Misses diaphragm, bowel, and \\
Bisadvantage & Bowel gas and SO air distorsion & Specificity: Low & some pancreatic injuries \\
& Misses diaphragm, bowel, & Misses injury to diaphragm and & Transport: Required \\
\hline
\end{tabular}

FAST* $^{*}$ focused assessment sonography in trauma

$\mathrm{DPL}^{\dagger}$ : diagnostic peritoneal lavage

Table 4. Indication of abdominal image or Diagnostic peritoneal lavage ${ }^{*}$ in asymptomatic patients

\author{
Head injury \\ Altered mentality due to alcohol intoxication, drug, etc \\ Spinal cord injury \\ Injury to adjacent structures such as rib, spine or pelvis
}

$\mathrm{DPL}^{*}$ : diagnostic peritoneal lavage

Table 5. Indications of emergency explolaparotomy

Shock after abdominal trauma
Evisceration of internal organ through abdominal wall injury
Presence of peritoneal irritation signs
Hemoperitoenum of pneumoperitoneum on images
Intra-abdominal organ injuries on image
Bladder rupture (intraperitoenal type)
Positive findings in DPL ${ }^{*}$ or paracentesis
Rectum perforation on rectal examination
When trauma surgeon suspects abdominal injury

경미한 장기손상 혹은 혈복증의 경우에는 단순히 관찰하는 경우가 많으므로 복강세척술의 사용이 급격히 감소하고 있 다. 복강에서 역류된 내용물의 검사에서 다음의 경우에는 복강내 장기손상이 있다고 판정한다(Table 2).

상기 영상검사법 중에서 신뢰도가 높은 진단방법으로는 복부 단층촬영(CT scan), 외상초음파검사(FAST), 진단적 복강세척술(DPL)인데, 환자 상태에 따라서 가장 적절한 검 사방법을 선택하는 것이 바람직하다. 쇼크 혹은 호흡곤란
Table 6. Essential tests for operations

Electrocardiograph(ECG)
$\mathrm{ABO}$ type with/without micro-matching
$\mathrm{CBC}$, electrolyte, glucose, amylase, blood alcohol
Pregnancy test in female
Urinalysis and urine drug screen

등으로 환자 상태가 매우 불안정한 경우에는 소생실 내에서 각종 검사 및 처치를 시행해야 하므로 외상초음파검사를 우 선 시행하는 것이 바람직하지만 초음파장비가 없는 상황에 서는 진단적 복강세척술을 시행하는 것이 안전하다. 환자 상태가 비교적 안정된 경우에는 시간적 여유를 갖고 복부 전산화단층촬영을 시행하는 것이 권장되며 복강내 장기 별 로 손상 정도를 파악할 수 있는 가장 정확한 검사방법일 것 이다. 각 검사방법에 따른 장단점은 table 3 과 같다.

둔상에 의한 다발성 외상환자에서는 신체검진에서 복부 자각증상이 없더라도 다음의 경우에는 방사선검사나 기타 검사방법을 이용하여 반드시 복부손상 유무를 진단해야 한 다 (Table 4).

특히, 소장이 천공된 초기 혹은 복강내 출혈이 경미한 경 우에는 복부자각증상이 거의 없고 혈압도 정상이므로 의식 이 명료하지 않거나 인접 장기의 손상이 심하거나(예; 늑골 골절, 골반골절 등) 혹은 몸통의 마비가 동반된 경우에는 복 부손상이 없는 것으로 간과하기 쉽다. 
Table 7. Indication and contraindication of gastric tube and urinary cathether

\begin{tabular}{lll}
\hline & Nasogatric tube insertion & Urinary catheter insertion \\
\hline \multirow{3}{*}{ Goal } & Relieve acute gastric dilatation & Decompress the bladder before DPL* \\
& Decompress stomach before DPL & Monitoring of urinary output in shock \\
& Reducing the risk of aspiration & \\
Early diagnosis & Early diagnosis \\
& All patients & All patients \\
Contraindication & Noninvasive & Performed rapidly \\
& Performed rapidly & $98 \%$ sensitive \\
& Repeatable & Detects bowel injury \\
& High accuracy: 86 97\% & Transport: No \\
& Transport: No & \\
\hline
\end{tabular}

$\mathrm{DPL}^{*}$ : diagnostic peritoneal lavage

Table 8. Advantages of laparoscopy in penetrating abdominal trauma

High diagnostic accuracy of diaphragm injury

Diagnosis and therapeutic effects

Merits of minimal invasive surgery

- minimal pain

- early recovery

- maintenance of immunity and metabolism

- cosmetic effect

Low incidence of negative explolaparotomy

\section{초기 응급처치}

복부외상이 의심되면 소생술(ABC's)을 시행하면서 외과 당직팀을 조기 호출하고 동시에 수술을 위한 준비를 병행하 는 것이 바람직하다. 복부외상 환자에서 개복술이 필요한 경우는 다음과 같다(Table 5). 복부손상이 의심되는 초기 단계부터 외과당직팀을 호출하여 각종 소요시간을 최소화 하는 것이 바람직하다. 응급의료진과 외과당직팀과의 협조 체계는 매우 중요한 사항인데, 수술이 필요한 불안정한 환 자의 경우 1 시간 이내에 수술실로 이송되는 것이 바람직하 며 병원내 외상팀이 있다면 외상팀장의 지휘체계를 최대한 활용해야 한다(3).

일단, 필수적인 소생술( $\mathrm{ABC}$ 's)을 시행하면서 소생실 내 에서 직접 외상초음파검사(FAST)를 시행하여 복강내 저류 액의 유무를 확인하며, 소생술을 시행하면서 혈액검사 및 소변검사를 의뢰하였는지 다시 확인한다(Table 6).
복부외상이 의심되면 위관 (gastric tube)과 요관(urinary catheter)을 삽입하는데 위 관을 삽입하여 위의 내용물을 제거함으로써 위팽만을 감소 시키고 구토에 의한 흡인을 예방하는 것이다. 요관을 삽 입함으로써 방광팽대를 감소 시키고 수액처치시 소변량을 관찰할 수 있다. 다만 다음의 사항에 주의해야 한다. 위관 을 삽입하기 전에는 신체검진으로 두개저골 골절 혹은 안면 골 골절이 있는지 확인해야 하며 안면골 골절이 의심되면 입을 통하여 위관을 삽입해야 한다. 즉 귀나 코로 뇌척수 액이 누출되는 경우나 촉진상 안면에서 골마찰(bony crepitus)가 의심되는 경우에는 입으로 삽입한다(Table 7). 안면골 골절이 있는 경우에 코를 통하여 위관을 삽입하면 가 끔 위관이 두개강(cranial cavity) 내로 위치하기 때문이다. 요관을 삽입하기 전에는 요로손상의 가능성의 유무를 확인 하고 요로손상의 가능성이 있는 경우에는 방광배액술 (cystostomy)를 고려해야 한다.

복부자상 환자의 경우에는 복강내 장기손상의 유무를 확 인하는 방법들(CT, 복강경검사, 상처의 부분절개술 등)이 있 으나 대부분 개복술을 권장하고 있다(3). 전산화단층촬영을 시행하는 경우에는 복부자상의 위치에 따라서 가급적 3개 의 조영제를 모두 사용하는 방법들(조영제의 정주, 위, 직 장)도 고려해야 한다. 최근에는 복부외상 환자에서 복강경 을 이용한 진단과 치료에 대한 각종 문헌이 제시되고 있으 며(4), 복강경의 이점은 table 8 과 같다.

\section{참고문헌}

1. Abdominal Trauma. In: American College of Surgeons Committee on Trauma. Advanced Trauma Life Support. 7th ed. American College of Surgeons 2007: 131-145.

2. Hong ES. Focused Assessment Sonography in Trauma. In: Korean Traumatology Society. Advanced Trauma Life Support. 2nd ed. Seoul: Kunja Co, 2005: 92-106. 
3. Choi YB. Abdominal Trauma. In: Korean Traumatology Society. Advanced Trauma Life Support. 2nd ed. Seoul: Kunja Co, 2005: 175-188.
4. Choi YB, Lim KS. Therapeutic laparoscopy for abdominal trauma. Surg Endosc 2003; 17: 421-427.

\section{Q Peer Reviewer Commentary}

\section{임 태 호 (한양의대 응급의학교실)}

본 논문은 복부외상 환자의 응급처치에 관하여 전문외상처치술(advanced trauma life support, ATLS)에 입각한 서론적 소개와 함께 변화하고 있는 진단 방법의 최신지견을 그 장단점과 함께 기술하고 있다. 필자가 밝힌 대로 최근 변화 중 복부 외상의 신속한 진단과 빠른 수술에 있어 반복적인 외상초음파검사(FAST)는 매우 중요한 진단도구가 되 고 있으며, 향후 초음파의 기계적 진보와 함께 그 중요도가 더욱 커지리라고 생각된다.

빠른 진단과 함께 필자가 강조하고 있는 외상 환자에 대한 정확한 응급의료체계 활성화 및 외상외과 혹은 외과 의사와 의 긴밀한 협조를 통한 빠른 수술 등은 개별 병원 내부 문제 및 의료수가 등의 국가적 지원정책 미비 등으로 시행에 많 은 어려움이 있는 것이 현실이다. 그러나 본 논문이 제시하고 있는 빠르고 정확한 진단, 안전한 처치, 빠른 근치적 수술 이라는 외상 환자의 치료 원칙은 강조되고 지켜져야 하며, 제시된 구체적인 방법들은 지속적으로 과학적 검증을 통하여 새로워져야 할 것이다.

\section{자율학습 7월호 (전립선 비대증) 정답}

1. (1)

2. (2)

3. (3)

4. (4)

5. (3)
6. (3)

7. (3)

8. (2)

9. (1)

10. (4) 